\title{
Benchmarks
}

\section{Construction of a Genomic DNA Library by TA Cloning}

BioTechniques 24:564-565 (April 1998)

The preparation of a good genomic DNA library is crucial for cloning a desired gene. However, one often encounters difficulty in such preparations because of insufficient digestion of genomic DNA with restriction enzymes for several reasons, including contamination of genomic DNA with tightly bound polysaccharides/proteins to genomic DNA and methylation of nucleotide residues. Consequently, some regions of the genome never generate fragments of suitable size for insertion into a cloning vector. In such cases, physical cleavage by sonication is used because more random cleavages are obtained. However, ligation with blunt ends with a cloning vector is far less efficient than ligation with cohesive ends. It is possible to prepare cohesive ends by addition of appropriate adapters to both blunt ends, but this process itself involves inefficient ligation with blunt ends and requires large numbers of adapters (5). Hence, the template-independent terminal transferase activity of Taq DNA polymerase has been used for modifying 3' blunt ends of genomic DNA fragments into $3^{\prime} \mathrm{A}$ overhangs $(1,2)$. We found that the subsequent TA ligation with a TA vector remarkably improved the efficiency for constructing a genomic DNA library. This method was applied to cloning a gene from the filamentous cyanobacterium Spirulina.

Preparations of cyanobacterial DNA usually contain many polysaccharides (3) and a large portion of methylated genomic DNA (4). Especially for Spirulina DNA, we encountered much difficulty in digestion with restriction en- zymes, even when the DNA was purified by $\mathrm{CsCl}$ gradient centrifugation. However, the present method gave a good result, even though a simple procedure was used for purification of genomic DNA using a commercial kit. A genomic DNA library of Spirulina platensis IAM-M135 was constructed using the following protocol. Total DNA was extracted using the Wizard ${ }^{\circledR}$ Genomic DNA Purification Kit (Promega, Madison, WI, USA) from a growth phase culture (optical density $\left.[\mathrm{OD}]_{550}=0.6\right)$. A solution of $5 \mu \mathrm{g}$ DNA in $0.4 \mathrm{~mL}$ of TE buffer $(10 \mathrm{mM}$ Tris- $\mathrm{HCl}$ and $1 \mathrm{mM}$ disodium EDTA, $\mathrm{pH}$ 7.5) was cleaved by a Model US300 ultrasonic homogenizer (Nippon Seiki, Tokyo, Japan). The DNA fragments were treated with mung bean nuclease (Takara, Otsu, Shiga, Japan) (2 $\mathrm{U} / \mu \mathrm{g}$ DNA/100- $\mu \mathrm{L}$ volume) at $37^{\circ} \mathrm{C}$ for $1 \mathrm{~h}$ to prepare blunt ends. We used mung bean nuclease at low concentra- 
tions to protect from excess digestion and chewing. After phenol extraction and ethanol precipitation, the DNA was incubated with Taq DNA polymerase

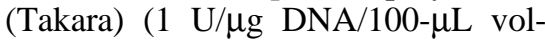
ume) and $2 \mathrm{mM}$ dATP in standard buffer [33 mM Tris-acetate, $\mathrm{pH}$ 7.9, 66 $\mathrm{mM} \mathrm{CH} \mathrm{CHOK}_{3} \mathrm{CO} \mathrm{mM} \mathrm{Mg}\left(\mathrm{CH}_{3}-\right.$ $\mathrm{COO})_{2}, 0.5 \mathrm{mM}$ dithiothreitol (DTT), $0.1 \mathrm{mg} / \mathrm{mL}$ bovine serum albumin (BSA)] at $70^{\circ} \mathrm{C}$ for $1 \mathrm{~h}$. DNA fragments were fractionated by agarose gel electrophoresis, and $1.5-3-\mathrm{kb}$ fragments were collected from the gel using the Prep-A-Gene ${ }^{\circledR}$ DNA Purification Kit (Bio-Rad, Hercules, CA, USA). Finally, the fragments were subjected to ligation with $50 \mathrm{ng}$ of pGEM ${ }^{\circledR}{ }_{-} \mathrm{T}$ vector (Promega) at $15^{\circ} \mathrm{C}$ for $4 \mathrm{~h}$. The ligation reactions are used to transform ELECTROMAX ${ }^{\circledR}$ DH10B ${ }^{\mathrm{TM}}$ Competent Cells (Life Technologies, Gaithersburg, MD, USA) using the Gene Pulser ${ }^{\circledR}$ II System (Bio-Rad). We thus obtained a genomic DNA library of $S$. platensis with an efficiency of $3 \times$ $10^{5}$ colonies/ $\mu \mathrm{g}$ vector DNA. From this library, we could clone the phytoene synthase gene, $\operatorname{crtB}$ (Accession No. AB001284) and the phytoene desaturase gene, crtP. By comparison, a conventional construction of a genomic library with Sau3A ends gave no success. Sequencing of the insert-containing clones revealed the insertion of a single TA base pair at both ends of the pGEM-T vector. The treatment with mung bean nuclease can be omitted, but the efficiency of colony formation will be reduced to $10^{3}$ colonies $/ \mu \mathrm{g}$ vector DNA. This method is applicable to many other organisms in which genomic DNA is difficult to digest by restriction enzymes.

\section{REFERENCES}

1.Clark, J.M. 1988. Novel non-templated addition reactions catalyzed by procaryotic and eucaryotic DNA polymerases. Nucleic Acids Res. 16:9677-9686.

2.Douglas, M., D. Mitchell, S. Ann and S.C. Fracis. 1991. Construction of T-vectors, a rapid and general system for direct cloning of unmodified PCR products. Nucleic Acids Res. 19:1154.

3.Jager, K. and M. Potts. 1988. Distinct fractions of genomic DNA from cyanobacterium Nostoc commune that differ in the degree of methylation. Gene 74:197-201.

4.Lambert, G.R. and N.G. Garr. 1984. Resistance of DNA from filamentous and unicellu- lar cyanobacteria to restriction endonuclease cleavage. Biochim. Biophys. Acta 781:45-55.

5.Sambrook, J., E.F. Fritsch and T. Maniatis. 1989. Molecular Cloning: A Laboratory Manual, 2nd ed. CSH Laboratory Press, Cold Spring Harbor, NY.

Address correspondence to Yoshikazu Kawata, Osaka National Research Institute, Organic Material Dept., Bioresource Engineering, 1-8-31 Midorigaoka, Ikeda, Osaka 5638577, Japan.
Received 29 July 1997; accepted 2 December 1997.

Yoshikazu Kawata, Shin'ichi Yano and Hiroyuki Kojima Osaka National Research Institute

Osaka, Japan 